\title{
NOWE STANOWISKO CAREX BUEKII (CYPERACEAE) NA PODGÓRZU RZESZOWSKIM
}

\section{NEW LOCALITY OF CAREX BUEKII (CYPERACEAE) IN THE RZESZÓW FOOTHILLS}

\author{
Piotr HaŁucha
}

\begin{abstract}
P. Hałucha, Biuro Urządzania Lasu i Geodezji Leśnej Oddział w Przemyślu, ul. Wysockiego 46a, 37-700 Przemyśl, Poland, e-mail: piotrhalucha@gmail.com, (i) https://orcid.org/0000-0002-3859-4102
\end{abstract}

Aвstract. Carex buekii is a rare species in Poland. In 2020, the new locality of this species was found in the Rzeszów Foothills (SE Poland, ATPOL grid square FF78).

KeY Words: vascular flora, rare species, Carex buekii, Cyperaceae, Poland

Carex buekii Wimm. (turzyca Bueka) jest gatunkiem występującym w środkowej i południowej Europie. Jej zasięg rozciaga się od centralnych Niemiec po zachodni Kazachstan i wschodnią Bułgarię (CHATER 1980).
Roślina osiąga wysokość od 40 do 120 cm, ma długie i grube, pełzające kłącze. Łodygi dołem są okryte charakterystycznie siatkowato postrzępionymi pochwami (fot. 1a). Kwiatostan jest zbudowany z 1-3

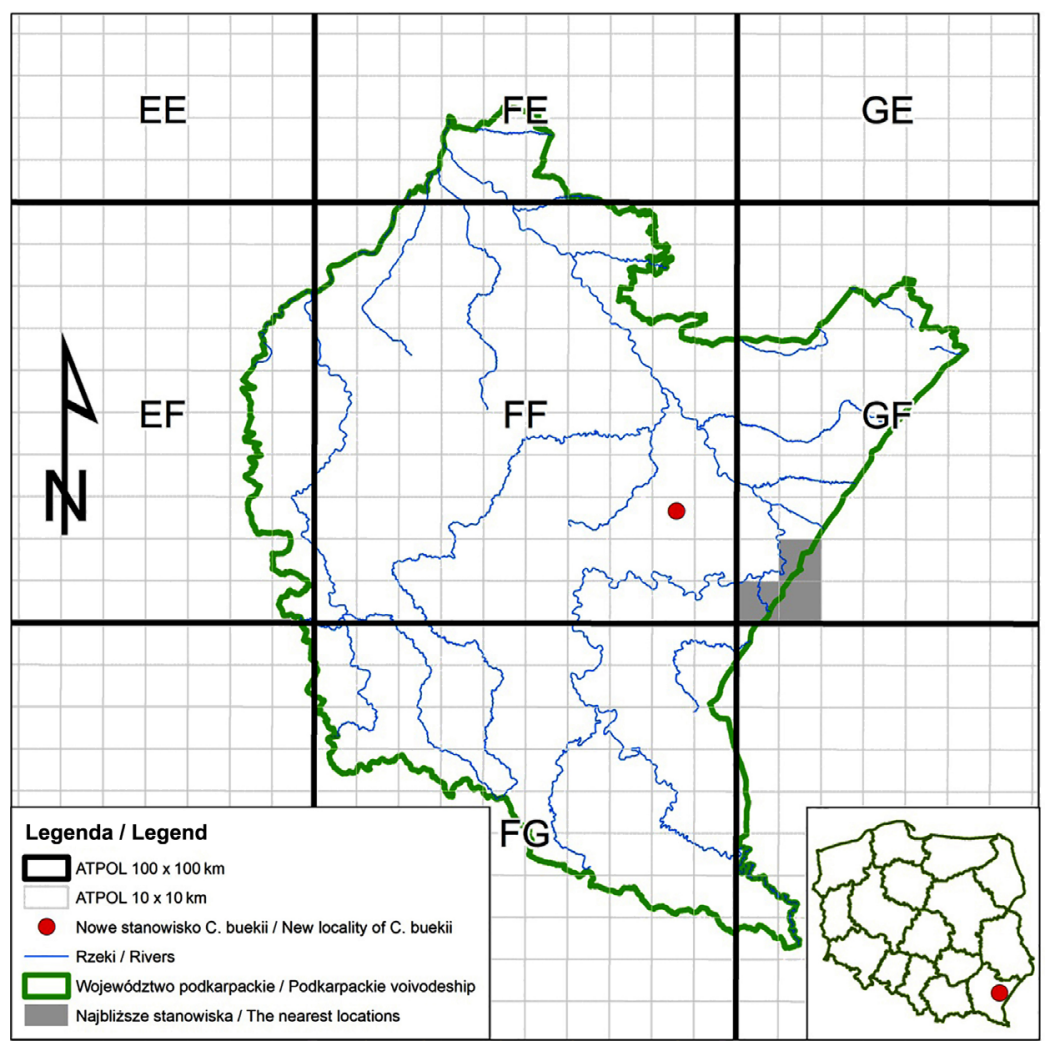

Ryc. 1. Nowe stanowisko Carex buekii na tle siatki ATPOL

Fig. 1. The new locality of Carex buekii on the background of the grid lines ATPOL 
kłosów męskich w części górnej i 3-5 kłosów żeńskich w części dolnej (fot. 1b). Kwitnie w kwietniu i maju (fot. 1c). Rośnie w miejscach wilgotnych, na brzegach wód, łąkach i moczarach (SzAFer i in. 1986).

W Polsce jest gatunkiem rzadkim, obecnie występującym głównie w jej południowej części. Został on umieszczony w „Polskiej czerwonej księdze roślin”, gdzie ma status gatunku bliskiego zagrożenia - kategoria NT (DAjDoK et al. 2014). Ponadto znalazł się na „Polskiej czerwonej liście paprotników i roślin
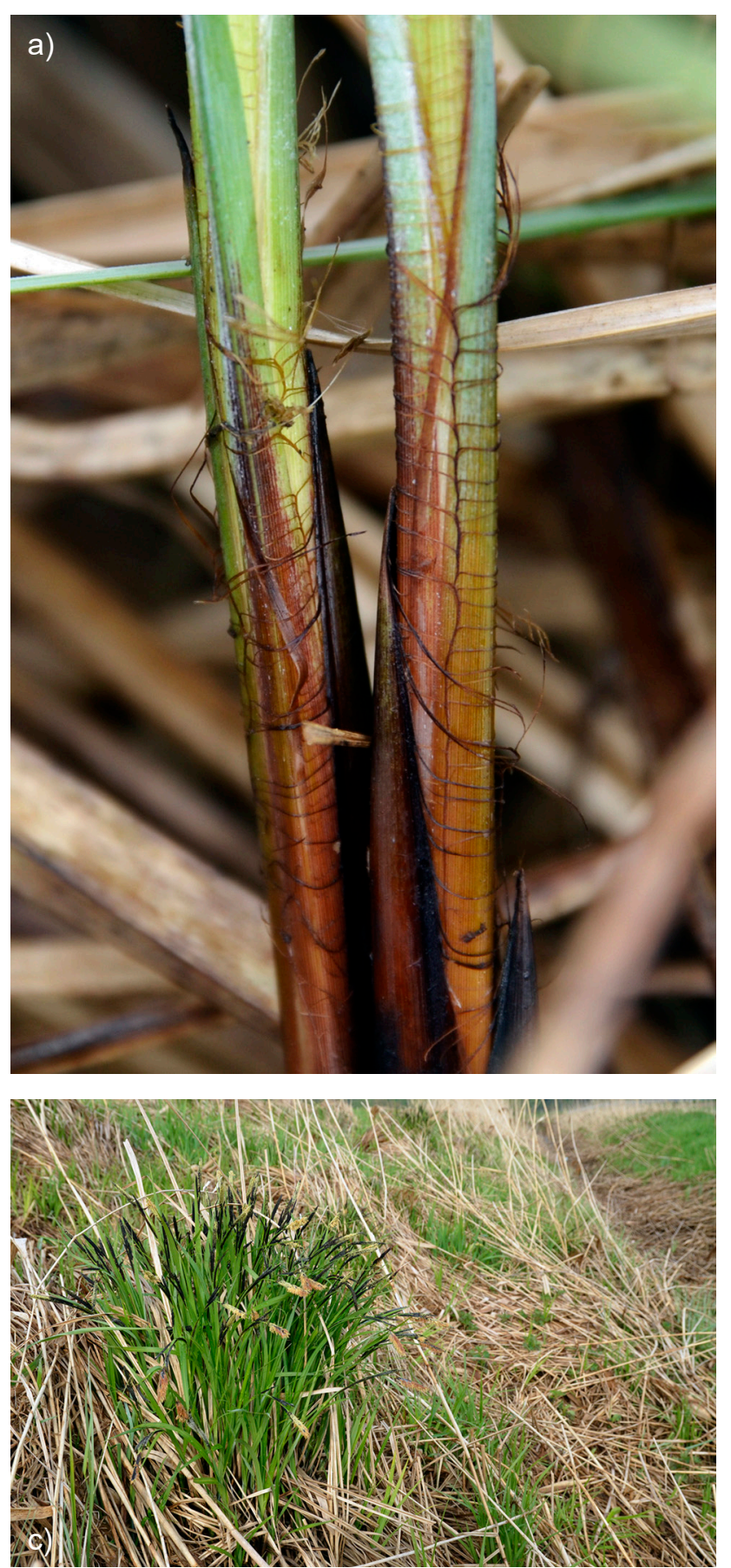

kwiatowych" jako gatunek bliski zagrożenia - kategoria NT (KAźMIERCZAKOWA $\mathrm{i}$ in. 2016).

$\mathrm{Na}$ Podgórzu Rzeszowskim turzyca Bueka była podawana $\mathrm{z}$ podtorfionej łąki w okolicach Rozborza (OchYRA 1974). Jednak pomimo intensywnych badań prowadzonych w ostatnich latach, nie udało się potwierdzić jej występowania w tym mezoregionie (JAźwa \& Stadnicka-Futoma 2017). Również na Pogórzu Przemyskim stanowisko podane przez Kotulę (1881) należy uznać za historyczne (WoLAnin 2014).
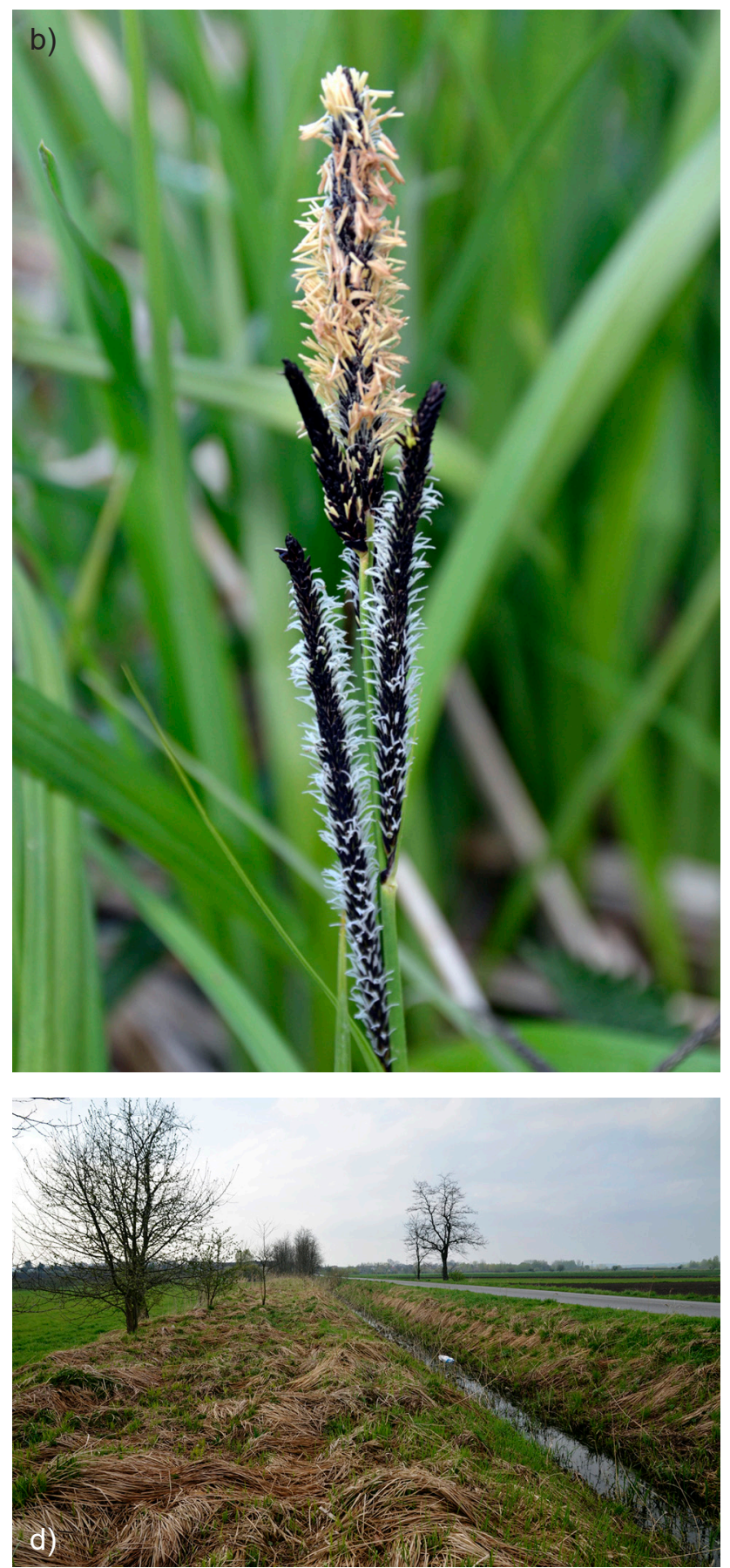

Fot. 1. Carex buekii na opisywanym stanowisku: a) charakterystycznie siatkowato postrzępione pochwy, b) kwiatostan, c) kępa w trakcie kwitnienia, d) wygląd ogólny stanowiska (fot. P. Hałucha)

Phot. 1. Carex buekii in the described location: a) characteristically reticulately fibrous-ragged shucks, b) inflorescence, c) clump during flowering, d) general appearance of the locality (photo: P. Hałucha) 
W 2020 roku odnaleziono nowe stanowisko turzycy Bueka w województwie podkarpackim (ryc. 1), na Podgórzu Rzeszowskim (Kondracki 2011). Według podziału ATPOL $(10 \times 10 \mathrm{~km})$ znajduje się ono w kwadracie FF78 (Zając 1978, Komsta 2016, Verey 2017). Gatunek zajmuje wąski pas (2-4 m szerokości) o długości kilkuset metrów. Ma on charakter rowu odwadniającego, który biegnie wzdłuż drogi łączącej miejscowości Cząstkowice i Bystrowice (fot. 1d). Turzyca rośnie na stromych brzegach rowu i na nasypie powstałym podczas jego kopania. Tworzy płaty, w których zdecydowanie dominuje oraz takie, gdzie gatunkiem współpanującym jest trzcina pospolita Phragmites australis (Cav.) Trin. ex Steud. Inne towarzyszące rośliny naczyniowe rosną z niewielkim pokryciem. Są to głównie: pokrzywa zwyczajna Urtica dioica L., przytulia czepna Galium aparine L., bodziszek łąkowy Geranium pratense L., jasnota plamista Lamium maculatum L., trybula leśna Anthriscus sylvestris (L.) Hoffm., ostrożeń polny Cirsium arvense (L.) Scop., podagrycznik pospolity Aegopodium podagraria L. oraz świerząbek korzenny Chaerophyllum aromaticum L. Miejscami występują zadrzewienia z robinią akacjową Robinia pseudoacacia L. Strefa, gdzie rośnie turzyca, w zdecydowanej większości znajduje się poza strefą wykaszanych poboczy i jest nieużytkowana, nie stwierdzono również śladów pogłębiania rowu. Populacja jest bardzo liczna, wydaje się stabilna i niezagrożona. Najbliższe istniejące opisywane stanowiska gatunku znajdują się w odległości około $30 \mathrm{~km}$. Są położone na wschód od Radymna - w okolicach miejscowości Nakło, w Medyce oraz na południowy wschód od Przemyśla - w okolicach miejscowości Łuczyce i Siedliska (Paul 2013).

\section{LITERATURA}

Chater A.O. (1980): Carex L. W: T.G. Tutin, V.H. Heywood, N.A. Burges, D.M. Moore, D.H. Valentine, S.M. Walters, D.A. Webb (red.). Flora Europaea 5. Alismataceae to Orchidaceae (Monocotyledones). Cambridge University Press, Cambridge: 290-323.

Dajdok Z., Wójcik G., Zarzyka-Ryszka M., Paul W. (2014): Carex buekii Wimm. Turzyca Bueka. W: R. Kaźmierczakowa, K. Zarzycki, Z. Mirek (red.).
Polska czerwona księga roślin. Instytut Ochrony Przyrody PAN, Kraków: 729-731.

JaźWa M., Stadnicka-Futoma A. (2017): Flora roślin naczyniowych Podgórza Rzeszowskiego. Komitet Biologii Organizmalnej PAN, Instytut Botaniki Uniwersytetu Jagiellońskiego, Warszawa-Kraków. Kaźmierczakowa R., Bloch-Orfowska J., Celka Z., Cwener A., Dajdok Z., Michalska-Hejduk D., Pawlikowski P., Szcześniak E., Ziarnek K. (2016): Polska czerwona lista paprotników i roślin kwiatowych. Polish red list of pteridophytes and flowering plants. Instytut Ochrony Przyrody PAN, Kraków.

Komsta Ł. (2016): Rewizja matematyczna siatki geobotanicznej ATPOL - propozycja algorytmów konwersji współrzędnych. Agronomy Science 71(1): 31-37.

KondRACKI J. (2011): Geografia regionalna Polski. Wydawnictwo Naukowe PWN, Warszawa.

Kotula B. (1881): Spis roślin naczyniowych w okolicy Przemyśla. Sprawozdanie Komisji Fizjograficznej Akademii Umiejętności 15: 1-90.

OCHYRA R. (1974): Notatki florystyczne z południowo-wschodniej części Kotliny Sandomierskiej. Zeszyty Naukowe Uniwersytetu Jagiellońskiego, Prace Botaniczne 2: 161-173.

PAul W. (2013): Rozmieszczenie roślin naczyniowych w południowej części Płaskowyżu Tarnogrodzkiego i terenów przyległych. Instytut Botaniki im. W. Szafera PAN, Kraków.

Szafer W., Kulczyński S., Pawłowski B. (1986): Rośliny polskie. T. 1-2. Wyd. 5. Państwowe Wydawnictwo Naukowe, Warszawa.

Verey M. (2017): Teoretyczna analiza i praktyczne konsekwencje przyjęcia modelowej siatki ATPOL jako odwzorowania stożkowego definiującego konwersję współrzędnych płaskich na elipsoidę WGS-84. Fragmenta Floristica et Geobotanica Polonica 24(2): 469-488.

Wolanin M. (2014). Rośliny naczyniowe Pogórza Przemyskiego i zachodniej części Płaskowyżu Chyrowskiego. Zeszyty Naukowe Uniwersytetu Jagiellońskiego, Prace Botaniczne 47: 1-383.

ZAJĄC A. (1978): Założenia metodyczne „Atlasu rozmieszczenia roślin naczyniowych w Polsce". Wiadomości Botaniczne 22(3): 145-155. 